\title{
ISOLATION AND MOLECULAR IDENTIFICATION OF A CELLULOTIC BACTERIUM FROM MUNCIPAL WASTE AND INVESTIGATION OF ITS CELLULASE PRODUCTION
}

\author{
ISOLAMENTO E IDENTIFICAÇÃO MOLECULAR DE UMA BACTÉRIA \\ CELULOLÍTICA DO LIXO MUNICIPAL E INVESTIGAÇÃO DE SUA PRODUÇÃO \\ DE CELULASE
}

\author{
Hojjatolah ZAMANI $^{1}$; Ali SALEHZADEH ${ }^{2 *}$; Mansoreh ABDOLHOSSEINI $^{2}$ \\ 1. Department of Biology, Faculty of Science, University of Guilan, Rasht, Iran; 2. Department of Biology, Rasht Branch, Islamic Azad \\ University, Rasht, Iran * salehzadeh@iaurasht.ac.ir
}

\begin{abstract}
Municipal waste is rich in lignocellulosic compounds which contain cellulose, lignin and hemicellulose. Microorganisms can break down such compounds and convert them into glucose and other carbohydrates. The current study was performed to isolate and identify cellulolytic bacteria in municipal waste. Municipal waste samples were collected and plated on Carboxymethyl cellulose (CMC) agar. Preliminary identification of the isolates was performed using standard biochemical assays. The activity of carboxymethyl cellulose (CMCase) was specified through measuring the release of reducing sugars from $\mathrm{CMC}$. Different nitrogen sources at various concentrations and initial $\mathrm{pH}$ values were evaluated for their effect on enzyme production. Further the enzyme production was determined at different fermentation times. Molecular identification was then performed using bacterial 16s rRNA gene amplification and sequencing. A cellulolytic bacterium was isolated from municipal waste samples and identified based on morphological, physiological and biochemical characteristics along with 16S rRNA analysis. The isolated bacterium was identified as Bacillus subtilis (accession number: KU681044). Whose growth characteristics showed that its growth curve entered the logarithmic phase following 10-18 h with the stable growth phase ranging from 23 to $37 \mathrm{~h}$. The optimal carbon source for fermentation was $1 \%$ rice hull, with the nitrogen source comprised of $2 \%$ peptone and yeast extract. The the minimum CMCase activity was observed at an initial medium $\mathrm{pH}$ of 4.0 , while the maximum was observed at $\mathrm{pH} 7$. The strain grew vigorously and the cellulase yield was high at 6-24 h fermentation time period. The isolated bacteria showed the degrading potential of cellulose which could be employed in local industrial process.
\end{abstract}

KEYWORDS: Bacillus subtilis. Carboxymethyl cellulose. KU681044. Lignocellulosic compounds. Municipal waste.

\section{INTRODUCTION}

The drastic augment in world population and the pace of urbanization, has led to an increase in municipal waste production. Recycling municipal waste in a natural way is the most novel and appropriate alternative considering other available options. Municipal waste is rich in Lignin-cellulosic material that basically contains cellulose and lignin and a low proportion of hemicelluloses (RAHMAN, 2004). Microorganisms can break down lignincellulosic materials, converting them into valuable products such as organic acids and antibiotics.

Cellulose is a polysaccharide with a crystalline form, which consists of repeating units of $D$ - glucose linked together via $\beta$ 1- 4 glycoside bonds (BHAT, 2000). The microbial degradation of cellulosic compounds is caused by an enzyme called cellulose, which hydrolyses the $\beta$ 1- 4 glycoside bonds of cellulose in order to release glucose units. Widely applied in different industries including food, feed, textile and pulp, cellulases have gained great significance in present day biotechnology. The bioconversion of cellulosic materials is currently a subject of intensive research as a contribution to the development of large scale conversion process beneficial to mankind (BEHERA et al., 2014).

Several bacterial and fungal species, such as aerobic and anaerobic bacterial and fungal strains, researched and reported. Cellulolytic bacterial species include Trichonympha, Clostridium, Actinomycetes and Ruminococcus species (GUPTA et al., 2012).

Despite the huge significance of cellulase in different industries, little is known as to the cellulolytic microbial species inhabiting municipal waste, hence the current research which was performed to isolate and identify bacterial species with cellulolose degrading potential in municipal waste landfill located in Saravan region, Rasht city, Iran. 


\section{MATERIAL AND METHODS}

\section{Sample collection}

The samples were collected from municipal waste landfill located in Saravan region, Rasht city, Iran. Sampling was performed at depths of 5-100 $\mathrm{cm}$ and the samples were collected in sterile container and stored at $4^{\circ} \mathrm{C}$ until used.

\section{Screening of cellulose producing bacteria}

Soil samples were serially diluted in sterilized distilled water, of which $0.1 \mathrm{ml}$ was plated on Carboxymethyl cellulose (CMC) medium which had the following composition (g/L) (Atlas R M 2010): carboxymethylcellulose (CMC), 10; $\mathrm{K}_{2} \mathrm{HPO}_{4}, 1.0 ; \quad \mathrm{KH}_{2} \mathrm{PO}_{4}, 1.0 ; \mathrm{MgSO}_{4} \cdot 7 \mathrm{H}_{2} \mathrm{O}, 0.2$; $\mathrm{NH}_{4} \mathrm{NO}_{3}, \quad 1.0 ; \quad \mathrm{FeCl}_{3} \cdot 6 \mathrm{H}_{2} \mathrm{O}, 0.05 ; \quad \mathrm{CaCl}_{2}, 0.02$; peptone, 2.0; Agar, 15.0. The incubation was performed at $37{ }^{\circ} \mathrm{C}$ for 3-5 days and the bacteria with cellulolose degrading potential were screened by flooding of $0.1 \%$ Congo red solution on the plates and washing with $1.0 \mathrm{M} \mathrm{NaCl}$ (APUN et al., 2000).

The formation of a clear zone around the bacterial colonies was regarded as cellulolytic activity. The cellulolytic activity was assessed through measuring the ratio of the clear zone diameter to colony diameter (ARIFFIN et al. 2006). The largest ratio was assumed to have the highest activity. The strain with high clearing zone was isolated for repeated screening. The strain (inoculum concentration of $1 \%, 50 \mathrm{~mL}$ in a $250 \mathrm{~mL}$ flask) was inoculated in liquid LB medium containing $1 \% \mathrm{CMC}$ at $37^{\circ} \mathrm{C}$ and grown with shaking at $220 \mathrm{rpm}$ for $24 \mathrm{~h}$. Subsequently, the fermentation extract was centrifuged at $5000 \mathrm{rpm}$ for $15 \mathrm{~min}$, and the apparent supernatant was examined for enzyme assays under optimum reaction conditions to screen most cellulolytic bacterial strains. Strains demonstrating giant cellulase activity were used in subsequent experiments.

\section{Morphological and physiological characterization of cellulolytic isolates}

Once the pure culture of the isolates was prepared, the bacterial isolates were initially identified by morphological examination and biochemical characterization. The parameters investigated were bacterial shape, Gram reactions, endospore formation, catalase production, VogesProskauer (V-P) reactions, starch hydrolysis, motility and citrate utilization.

\section{Effect of different fermentation conditions on cellulase production}

In order to specify the optimal carbon and nitrogen source to intensify cellulase production, different carbon and nitrogen sources at various concentrations and initial $\mathrm{pH}$ values were assessed for their effect on enzyme production. Also simultaneously enzyme production at different fermentation times was dogged. Cultures $(50 \mathrm{~mL}$ in $250 \mathrm{~mL}$ flasks) were incubated at $37^{\circ} \mathrm{C}$ on a rotary shaker at $220 \mathrm{rpm}$ for $24 \mathrm{~h}$, the fermentation extract was centrifuged at $5000 \mathrm{rpm}$ for $15 \mathrm{~min}$, and the apparent supernatant was employed in the enzyme assays.

\section{Molecular identification of the isolates}

Bacterial genomic DNA was extracted using the previously described method with a minor modification (DAS; DASH, 2015). Briefly, $5 \mathrm{~mL}$ of Bacterial suspensions grown in Luria-Bertani (LB) broth were centrifuged $(6000 \mathrm{~g} / 10 \mathrm{~min})$ and the pellet was re-suspended in TE buffer. Then, $30 \mu \mathrm{L}$ of $10 \%$ SDS and $3 \mu \mathrm{L}$ of $20 \mathrm{mg} / \mathrm{mL}$ proteinase-K were added to each tube and incubated for $60 \mathrm{~min}$ at $37^{\circ} \mathrm{C}$. Next, $\quad 600 \mu \mathrm{L}$ of $25: 24: 1$ phenol/chloroform/isoamyl alcohol solution was added and centrifuged at $6000 \mathrm{~g}$ for 5 minutes. Finally, one volume of cold ethanol was added to the supernatant and the DNA was precipitated following centrifugation $(10 \mathrm{~min}$ at $8,000 \mathrm{~g})$. The DNA yield was re-suspended in TE buffer and stored at $-20^{\circ} \mathrm{C}$ for subsequent analysis.

Polymerase Chain Reaction (PCR) was employed to amplify bacterial 16S rRNA gene. The master mix for the PCR was prepared as follows: $3 \mu \mathrm{L}$ of $10 \times$ PCR buffer, $1 \mu \mathrm{L}$ of $25 \mathrm{mM} \mathrm{MgCl}_{2}$, $3 \mu \mathrm{Lof} 10 \mathrm{mM}$ dNTP mix, $0.5 \mu \mathrm{L}$ of Taq DNA Polymerase, $12.5 \mu \mathrm{L}$ of MilliQ water and $1 \mu \mathrm{L}$ of the forward and reverse primers. Ultimately, $3 \mu \mathrm{L}$ of each DNA template was added in the corresponding tubes to make up the final reaction volume of $25 \mu \mathrm{L}$.

Bacterial 16S rRNA gene was amplified using 27F (5' AGAGTTTGATCCTGGCTCAG 3') and $1107 \mathrm{R}$ (5' AAGGTTACCTCACCGACTTC 3') universal primers (LANE, 1991). The thermal cycler was programmed as follows: $5 \mathrm{~min}$ at $94^{\circ} \mathrm{C} ; 30$ cycles of $45 \mathrm{~s}$ at $94^{\circ} \mathrm{C}, 1 \mathrm{~min}$ at $58^{\circ} \mathrm{C}, 1 \mathrm{~min}$ at $72^{\circ} \mathrm{C}$ and $10 \mathrm{~min}$ at $72^{\circ} \mathrm{C}$. The PCR product was sequenced for 16S rRNA (Macrogen, South Korea). The sequencing results were compared via applying the Basic Local Alignment Search Tool (BLAST) program to NCBI and 16S rRNA gene sequence homology analysis using GenBank data. A phylogenetic tree was constructed using the neighbor-joining model of the MEGA 5 program. 


\section{RESULTS AND DISCUSSION}

In the present study, the isolated species were cultured at $37^{\circ} \mathrm{C}$ on CMC-Na solid media for $24 \mathrm{~h}$, where the subsequent Congo red staining showed a remarkable clearing zone. Furthermore, by testing the enzyme activity, we selected the strain demonstrate the highest enzyme activity for upcoming research. According to preceding research, the enzyme activity of this strain (2.1 $\mathrm{U} / \mathrm{mL}$ ) was higher than that of other strains cultured for $24 \mathrm{~h}$ (SINGH et al., 2013; IMMANUEL et al., 2006; REDDY et al., 2017) suggesting that this strain exhibits steady inheritance and has strong CMCase activity. The morphological and physiological characteristics of isolated strain were further determined (Table 1), according to which results, the strain was Gram positive rod.

Table 1. Morphological and physiological characterizations of the isolated strain.

\begin{tabular}{lccccccccc}
\hline Characters & shape & $\begin{array}{c}\text { Gram } \\
\text { stain }\end{array}$ & spore & $\begin{array}{c}\text { Catalase } \\
\text { Test }\end{array}$ & $\begin{array}{c}\text { VP } \\
\text { growth }\end{array}$ & motility & $\begin{array}{c}\text { Citrate } \\
\text { utilization }\end{array}$ & $\begin{array}{c}\text { starch } \\
\text { hydrolysis }\end{array}$ \\
\hline CS1 & Rod & + & + & + & + & + & - & + & + \\
\hline
\end{tabular}

The 16S rRNA sequence of the cellulolytic bacterium was 1511 bp long. This sequence was compared with the database of known 16S rRNA sequences. Homology analysis showed that the sequence similarity of this strain to certain Bacillus species exceeded $95 \%$. Thus, all characterization methods indicated that the isolated species was a $B$. subtilis strain (KIM et al., 2009). The 16S rRNA gene sequence of the isolate was submitted to the
GenBank with KU681044 accession number. As shown in the phylogenetic tree constructed using MEGA5, the strain is related to B. subtilis (GenBank accession number: NR_118383.1), with a similarity of $97 \%$. Therefore, all characterization methods showed that the isolated species was a $B$. subtilis strain.The phylogenic tree of the isolated bacterium is illustrated in Figure 1.

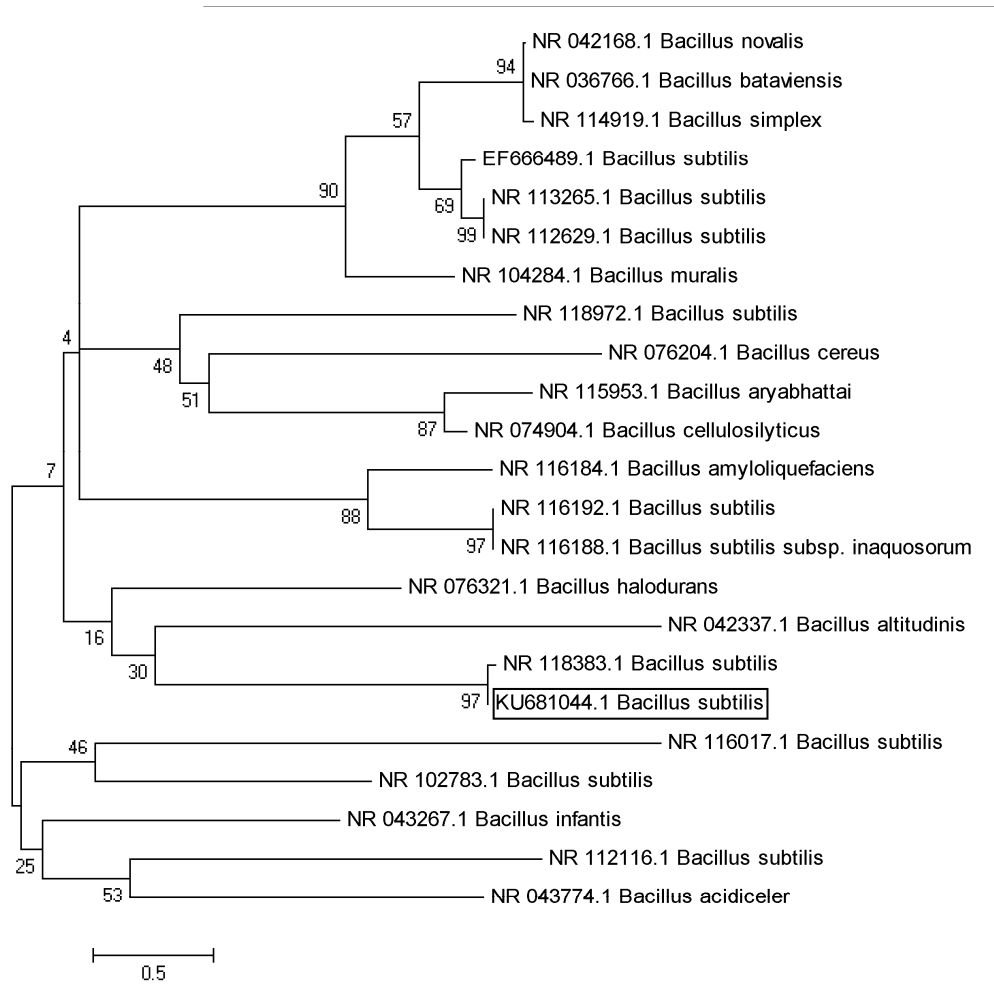

Figure 1. Phylogenic analysis of cellulolytic strain isolated in this study (Accession number: KU681044). Bootstrap values based on 500 replications are given at the branching points.

The strain attained the logarithmic phase at $10-18 \mathrm{~h}$ after inoculation, after which its growth hit a plateau and proceeded for approximately $20 \mathrm{~h}$ (Figure 2). 


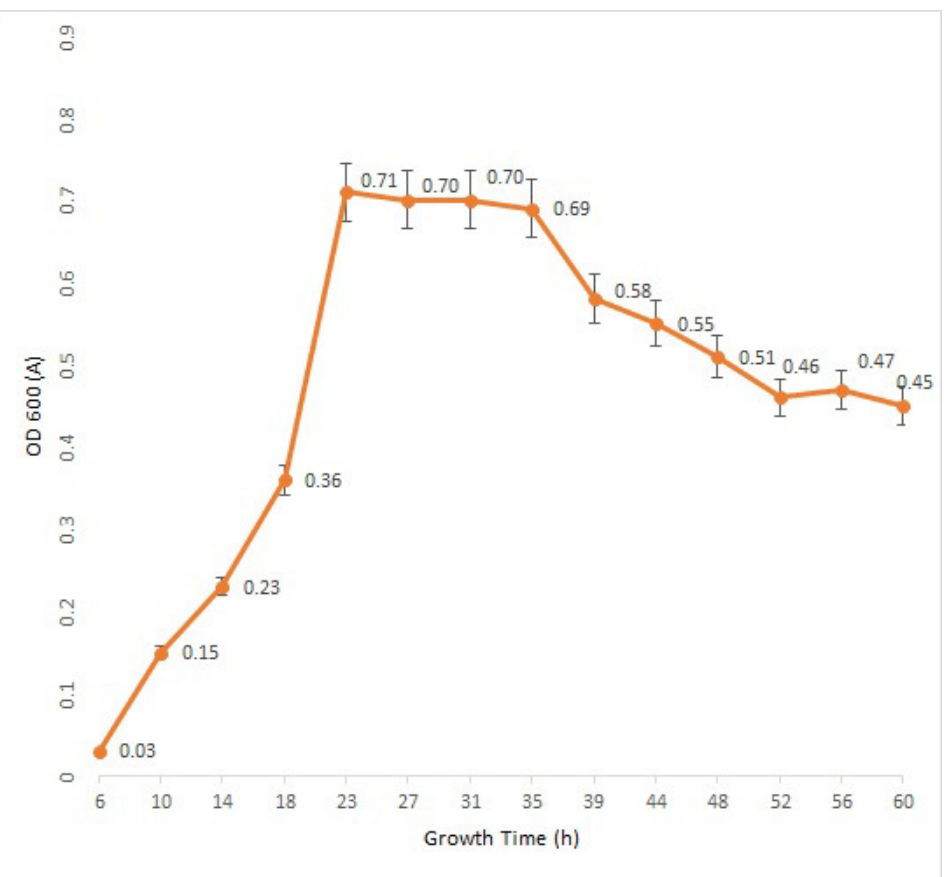

Figure 2. Growth curve of isolated bacteria. Error bars indicate standard deviation.

According to the strain growth characteristics, we concluded that the optimum enzyme production time was $18-35 \mathrm{~h}$. Considring the fact that bacterial enzyme is most active in the logarithmic phase, we organized fermentation cultivation for $24 \mathrm{~h}$ in a follow-up experiment in order to investigate the enzyme features.

Since cellulase is an inducible enzyme, the medium for cellulose production in fermentation usually contains cellulose-rich substrates for a carbon source (LEE et al., 2008; DORSAM et al. 2017; ZHAO). In this medium, different carbon sources were tested at different concentrations in order to study their effects on cellulase production under uniform conditions (incubation time, $24 \mathrm{~h}$; rotation speed, $220 \mathrm{rpm}$; temperature, $37^{\circ} \mathrm{C}$; seeded culture concentration, $1 \%$ ). The results showed that the strain could employ varied carbon sources, and the maximal CMCase activity $(2.9 \mathrm{U} / \mathrm{mL})$ was detectet in a mixture of $1 \%$ rice hull and $1 \%$ CMC utilized as the sole carbon source. In accordance to Yang et al., however, when MCC was used as a sole carbon source, slight CMCase activity was observed (YANG et al., 2014). Consequently, the cheap and easily accessable rice hull was found to be an optimal carbon source applicable in subsequent experiments (Figure 3 ).

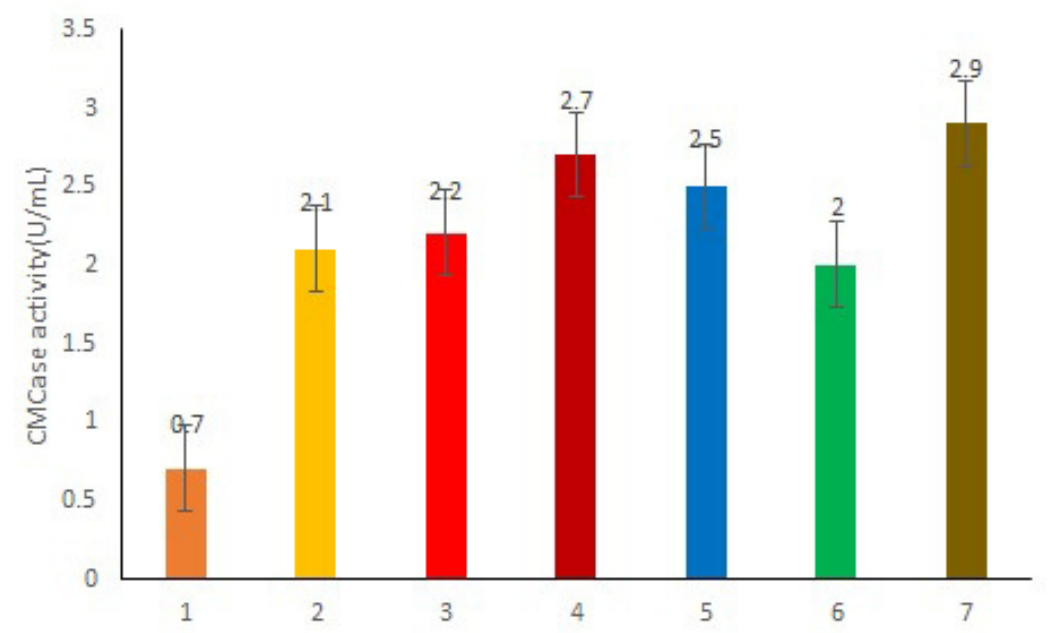

Figure 3. Effect of different carbon sources on cellulase production(1: $1 \% \mathrm{MCC} ; 2: 1 \% \mathrm{CMC}+1 \%$ Wheat Bran; 3: 1\% Wheat Bran; 4: Rice hull; 5: 1\% CMC; 6: 2\% CMC; 7: 1\% CMC+Rice hull) . Error bars indicate standard deviation. 
Different nitrogen sources $(1 \%$ yeast extract, $1 \%$ peptone, a $1: 1$ mixture of $1 \%$ peptone and yeast extract, a 1:1 mixture of $2 \%$ peptone and yeast extract, and $1 \% \mathrm{NH} 4 \mathrm{OH}$ ) were examined. The results showed that the strain can efficiently exploit organic nitrogen sources. Moreover, the maximum
CMCase activity $(2.4 \mathrm{U} / \mathrm{mL})$ was observed when a $1: 1$ mixture of $2 \%$ peptone and yeast extract was used as the only nitrogen source. Nevertheless, the CMCase activity was nearly zero with inorganic nitrogen sources (NH4OH) (Figure 4).

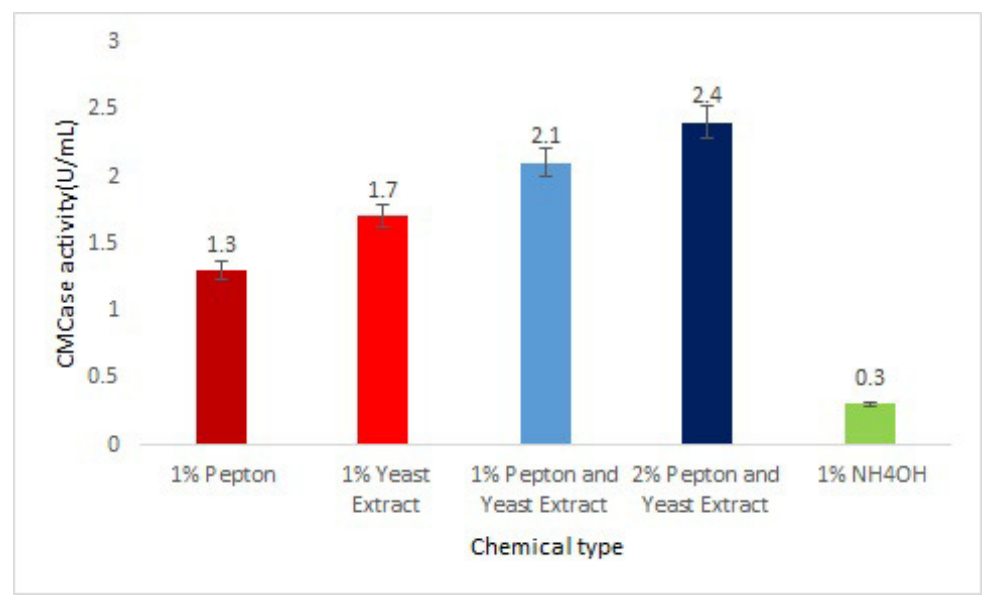

Figure 4. Effect of different nitrogen sources on cellulase production. Error bars indicate standard deviation.

The reason is that the metabolism of inorganic nitrogen conduces to medium acidification, which in turn affects cellulase production. The Bacillus species isolated by Rajoka (2014) and Ray et al. (2007) showed the same capability with regards to nitrogen sources. In addition, the $B$. subtilis strain isolated by Acharya and Chaudhary (2011) was not capable of employing inorganic nitrogen sources when CMC was used as the carbon source; it was, however, able to employ these sources when wheat straw and rice hull were used as the carbon source.
To investigate the effect of $\mathrm{pH}$ on cellulase production, the $\mathrm{pH}$ of the medium was adjusted to 3.0, 4.0, 5.0, 6.0, 7.0, and 8.0. The CMCase activity in each $\mathrm{pH}$-adjusted medium was then measured under identical conditions (rotation speed, $220 \mathrm{rpm}$; temperature, $37^{\circ} \mathrm{C}$; seeded culture concentration, $1 \%$; incubation time, $24 \mathrm{~h}$ ). The minimum CMCase activity $(0.3 \mathrm{U} / \mathrm{mL})$, based on the results, was seen at an initial medium $\mathrm{pH}$ of 4.0 , while the maximum $(2.2 \mathrm{U} / \mathrm{mL}$ ) was observed at $\mathrm{pH} 7$ (Figure 5).

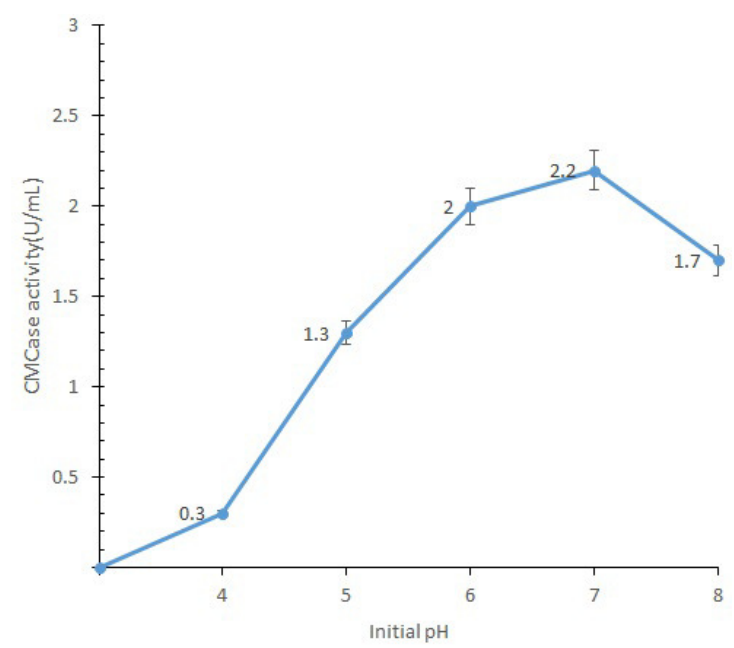

Figure 5. The effect of initial $\mathrm{pH}$ on cellulase production. Error bars indicate standard deviation. 
The optimal initial $\mathrm{pH}$ of strains varies depending on the source: for instance, the optimal initial $\mathrm{pH}$ for cellulase production by Bacillus isolated from a hot spring (ACHARYA; CHAUDHARY, 2011) was 9.0. Accordinlgy, suitable $\mathrm{pH}$ conditions can be conducive to the growth of strains and the increase in cellulase yield, a fact probably associated with the negative feedback mechanism of enzymes.

At various fermentation times the CMCase activity was measured at $37^{\circ} \mathrm{C}, 5.5 \mathrm{pH}$ and $220 \mathrm{rpm}$ with the use of optimal carbon and nitrogen sources. The findings showed significant variations in cellulase production at different times. The strain grew strongly and the cellulase yield was high when the fermentation time fell between 6-24 h. Suitable CMCase activity $(2.8 \mathrm{U} / \mathrm{mL})$ was perceived following $24 \mathrm{~h}$ cultivation; a reduction, nevertheless, was observed in this activity from $24 \mathrm{~h}$ to $36 \mathrm{~h}$. The CMCase activity reached its maximum $(3.0 \mathrm{U} / \mathrm{mL})$ when the fermentation time was $48 \mathrm{~h}$, following which time, it decreased sharply (Figure 6).

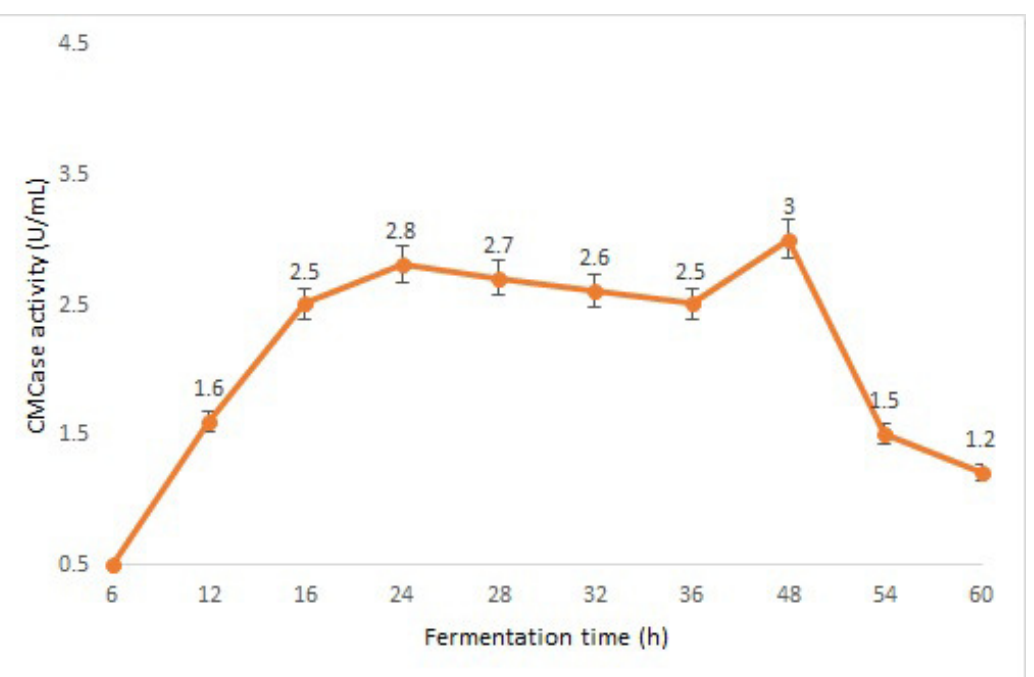

Figure 6. The effect of fermentation time on cellulase production. Error bars indicate standard deviation.

The fermentation time of the strain concerning the maximum cellulase yield was shorter than that of the Bacillus strains isolated by Rastogi et al. (2010), Sadhu et al. (2013) and comparable to that of Bacillus species isolated by Acharya and Chaudhary (2011).

Cellulose, as the main structural part of plants, is the most abundant organic carbon on earth. The organic carbon in the environment is mainly recycled by microorganisms (CLEMMER; TSENG, 1986; SI et al., 2017). On the other hand, the degradation of cellulose is a complex process and requires the cooperation of cellulolytic microbial enzymes. Successful biological conversion of cellulose-containing compounds depends on the nature of the cellulose, cellulolytic enzyme source, and the optimum conditions for catalytic activity and enzyme production.

RESUMO: Resíduos urbanos são ricos em compostos lignocelulósicos que contêm celulose, lignina e hemicelulose. Microrganismos podem quebrar esses compostos e convertê-los em glicose e outros carboidratos. O presente estudo foi realizado para isolar e identificar bactérias celulolíticas em resíduos urbanos. Amostras de resíduos municipais foram coletadas e plaqueadas em ágar Carboximetilcelulose (CMC). A identificação preliminar dos isolados foi realizada utilizando ensaios bioquímicos padrão. A atividade da carboximetilcelulose (CMCase) foi especificada através da medição da liberação de açúcares redutores da CMC. Diferentes fontes de nitrogênio em várias concentrações e valores iniciais de pH foram avaliados quanto ao seu efeito na produção de enzimas. Além disso, a produção de enzima foi determinada em diferentes tempos de fermentação. A identificação molecular foi então realizada utilizando amplificação e sequenciamento do gene bacteriano 16s rRNA. Uma bactéria celulolítica foi isolada de amostras de resíduos urbanos e identificada com base em características morfológicas, fisiológicas e bioquímicas, juntamente com a análise 16S rRNA. A bactéria isolada foi identificada como Bacillus subtilis (número de acesso: KU681044). Cujas características de crescimento mostraram que sua curva de crescimento entrou na fase logarítmica após 10-18 h com a fase de crescimento estável variando de 23 a $37 \mathrm{~h}$. A fonte de carbono ótima para a fermentação foi $1 \%$ de casca de arroz, com a fonte de nitrogênio composta de $2 \%$ de peptona e extrato de levedura. A atividade mínima de CMCase foi observada em um pH médio inicial de 4,0, enquanto a máxima foi observada em $\mathrm{pH}$ 7. A linhagem cresceu vigorosamente e o rendimento de celulase foi alto no período de 6 a 
24 horas de fermentação. As bactérias isoladas mostraram o potencial de degradação da celulose que poderia ser empregada no processo industrial local.

Resíduos municipais

PALAVRAS-CHAVE: Bacillus subtilis; Carboximetilcelulose; KU681044; Compostos lignocelulósicos;

\section{REFERENCES}

ACHARYA, S.; CHAUDHARY, A. Effect of nutritional and environmental factors on cellulases activity by thermophilic bacteria isolated from hot spring. J. Sci. Ind. Res., New Delhi, v. 70, p. 142-148, 2011.

APUN, K.; JONG B. C.; SALLEH, M. A. Screening and isolation of a cellulolytic and amylolytic Bacillus from sago pith waste. J. Gen. \& Appl. Microbiol., Tokyo, v. 46, p. 263-267, 2000.

ARIFFIN, H.; ABDULLAH, N.; UMI KALSOM, M. S. Production and characterization of cellulase by Bacillus pumilus EB3. Int. J. Eng. Technol., Dubai, v. 3, n. 1, p. 47-53, 2006.

ATLAS, R. M. Handbook of microbiological media. CRC press, Boca Raton, pp. 1451, 2010.

BHAT, M. K. Cellulases and related enzymes in biotechnology. Biotechnol. Adv., Berlin, v. 18, n. 5, p. 355383, 2000. https://doi.org/10.1016/S0734-9750 (00)00041-0

BEHERA, B. C.; PARIDA, S.; DUTTA, S. K. Isolation and identification of cellulose degrading bacteria from mangrove soil of Mahanadi River Delta and their cellulase production ability. Am. J. Microbiol. Res., Newark, v. 2, n. 1, p. 41-46, 2014. doi: 10.12691/ajmr-2-1-6

CLEMMER, J. E.; TSENG, C. L. Identification of the major anaerobic end products of Cellulomonas sp. (ATCC 21399). Biotechnol. Lett., Amsterdam, v. 8, n. 11, p. 823-826, 1986.

https://doi.org/10.1007/BF01020832

DAS, S.; DASH, H. R. Microbial Biotechnology-A Laboratory Manual for Bacterial Systems. Springer, New Delhi, pp. 239, 2015. doi:10.1007/978-81-322-2095-4

DORSAM, S.; FESSELER, J.; GORTE O.; HAHN, T.; ZIBEK, S.; SYLDATK, C.; OCHSENREITHER, K. Sustainable carbon sources for microbial organic acid production with filamentous fungi. Biotechnol Biofuels., London, v. 10, p. 242, 2017. doi:10.1186/s13068-017-0930-x

GUPTA, P.; SAMANT, K.; SAHU, A. Isolation of cellulose-degrading bacteria and determination of their cellulolytic potential. Int. J. Microbiol., Cairo, v. 2012, Article ID 578925, 2012. doi:10.1155/2012/578925

IMMANUEL, G.; DHANUSHA, R.; PREMA, P.; PALAVESAM A. Effect of different growth parameters on endoglucanase enzyme activity by bacteria isolated from coir retting effluents of estuarine environment. Int. J. Environ. Sci. Technol., Tehran, v. 3, p. 25-34, 2006. https://doi.org/10.1007/BF03325904

KIM, E. S.; LEE, H. J.; BANG W. G. Functional characterization of a bacterial expansin from Bacillus subtilis for enhanced enzymatic hydrolysis of cellulose. Biotechnol. \& Bioeng., Berlin, v. 102, n. 5, p. 1342-1353, 2009. doi: 10.1002/bit.22193

LANE, D. J. 16S/23S rRNA sequencing. Nucleic acid techniques in bacterial systematics. In E. Stackebrandt and M. Goodfellow (ed.), John Wiley \& Sons, New York, pp. 115-175, 1991.

LEE, Y. J.; KIM, B. K.; LEE, B. H.; JO, K. I.; LEE, N. K.; CHUNG, C. H. Purification and characterization of cellulase produced by Bacillus amyoliquefaciens DL-3 utilizing rice hull. Bioresour Technol., Lucknow, v. 99, p. 378-86, 2008. https://doi.org/10.1016/j.biortech.2006.12.013 
RAHMAN, M. H. Composting of solid waste in Bangladesh. In the Proceedings of the 19th International Conference on Solid Waste Technology and Management, Philadelphia, USA, 2004.

RAJOKA, M. I. Influence of various fermentation variables on exo-glucanase production in Cellulomonas flavigena. Electron. J. Biotechnol., Valparaíso, v. 7, n. 4, p. 257-263, 2004. doi: 10.2225/vol7-issue3-fulltext2

RASTOGI, G.; BHALLA, A.; ADHIKARI, A.; BISCHOFF, K. M., HUGHES, S. R.; CHRISTOPHER, L. P. Characterization of thermostable cellulases produced by Bacillus and Geobacillus strains. Bioresour Technol., Lucknow, v. 10, p. 8798-8806, 2010. https://doi.org/10.1016/j.biortech.2010.06.001

RAY, A.; BAIRAGI, A.; SARKAR GHOSH, K., SEN, S. K. Optimization of fermentation conditions for cellulase production by Bacillus subtilis CY5 and Bacillus circulans TP3 isolated from fish gut. Acta Ichthyol. Piscat., Szczecin, v. 37, p. 47-53, 2007.

REDDY, K. V.; VIJAYALASHMI, T.; RANJIT, P.; RAJU, M. N. Characterization of Some Efficient Cellulase Producing Bacteria Isolated from Pulp and Paper Mill Effluent Contaminated Soil. Braz. Arch. Biol. Technol., Curitiba, v. 60, e17160226. 2017. http://dx.doi.org/10.1590/1678-4324-2017160226

SADHU, S.; GHOSH, P. K.; DE, T. K.; MAITI, T. K. Optimization of cultural condition and synergistic effect of lactose with carboxymethyl cellulose on cellulase production by Bacillus sp. isolated from fecal matter of elephant (elephas maximus). Adv. Microbiol., Beijing, v. 3, p. 280-288, 2013. doi: 10.4236/aim.2013.33040

SI, G.; , PENG, C.; YUAN, J.; XU, X.; ZHAO, S.; XU, D.; WU, J. Changes in soil microbial community composition and organic carbon fractions in an integrated rice-crayfish farming system in subtropical China. Sci. Rep., London, v. 7, n. 2856, 2017. doi:10.1038/s41598-017-02984-7

SINGH, S.; MOHOLKAR, V. S.; GOYAL, A. Isolation, identification, and characterization of a cellulolytic Bacillus amyloliquefaciens strain SS35 from rhinoceros dung. ISRN Microbiol., Cairo, v. 2013, p. 1-7, 2013. http://dx.doi.org/10.1155/2013/728134

YANG, W.; MENG, F.; PENG J.; HAN, P.; FANG, F.; MA, L.; CAO, L. Isolation and identification of a cellulolytic bacterium from the Tibetan pig's intestine and investigation of its cellulase production. Electron. J. Biotechnol., Valparaíso, v. 17, n. 6, p. 262-267, 2014. http://dx.doi.org/10.1016/j.ejbt.2014.08.002

ZHAO, H.; XIA J.; WANG, J.; YAN, X.; WANG, C.; LEI, T.; XIAN, M.; Zhang, H. Production of bacterial cellulose using polysaccharide fermentation wastewater as inexpensive nutrient sources. Biotechnol. Biotec. Eq., London, 2018. doi: 10.1080/13102818.2017.1418673 